\title{
Geochemistry of
}

Ground Water in Mine

Drainage Problems

GEOLOGIGAL SURVEY PROFESSIONAL PAPER 473-A

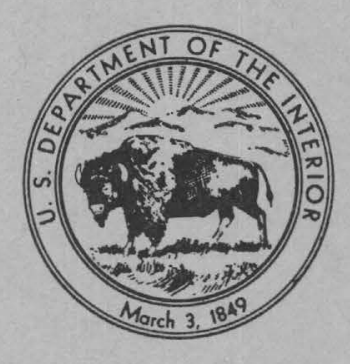





\section{Geochemistry of}

Ground Water in Mine

Drainage Problems

By IVAN BARNES and F. E. CLARKE

MINING HYDROLOGY

GEOLOGICAL SURVEY PROFESIONAL PAPER 473-A

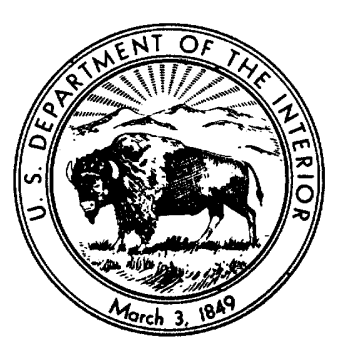

UNITED STATES GOVERNMENT PRINTING OFFICE, WASHINGTON : 1964 


\section{UNITED STATES DEPARTMENT OF THE INTERIOR STEWART L. UDALL, Secretary GEOLOGIGAL SURVEY \\ Thomas B. Nolan, Director}




\section{CONTENTS}

Abstract...
Introduction.
Role of air and organisms
Oxidation-reduction, a major factor.
Possible anaerobic reactions.

\section{TABLES}

TABLE 1. Maximum range concentration of $\mathrm{Fe}^{+3}$

\section{ILLUSTRATIONS}

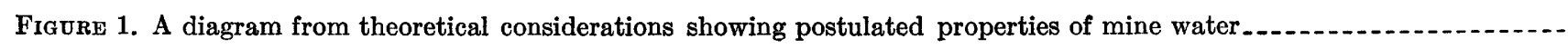

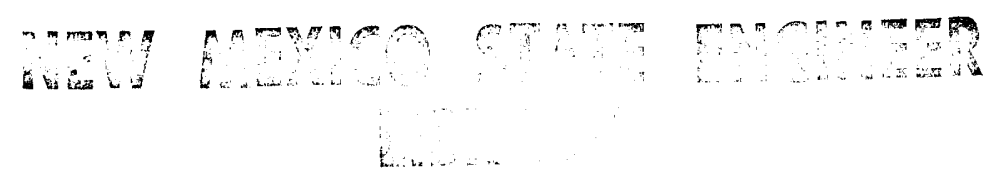





\title{
MINING HYDROLOGY
}

\section{GEOCHEMISTRY OF GROUND WATER IN MINE DRAINAGE PROBLEMS}

\author{
By Ivan Barnes and Frank E. Clarke
}

\begin{abstract}
From information readily available in the literature, the compositions of mine waters are considered and possible reactions that yield such compositions are examined. Both matter balances and thermodynamic considerations indicate that reactions taking place in the mines probably do not involve significant amounts of dissolved oxygen. The reactions do, however, involve water and coexisting geologic materials (minerals and probably coal if present), which, in the absence of side reactions with carbonates, yield an acidic and strongly reduced solution. In the absence of active mine ventilation, mine water is an anaerobic solution. Major implications of the theoretical model bear on the treatment processes feasible for reducing the effect of acid mine water on surface-water resource:
\end{abstract}

\section{INTRODUCTION}

Extensive literature exists on the subject of acid coal-mine waters and includes comprehensive reviews by Ash and others (1951, 1957), Moulton (1957), Hanna and others (1961), and Lorenz (1962). Numerous theories, arguments, and contradictions can be found on all phases of the subject, including causes, mechanisms, treatments, biologic agencies, disposal, prevention, and even whether or not such a problem exists.

Coal-mine water contains iron and sulfate in solution, and the water is generally acid in the absence of limestone. No obvious method for completely sealing mines, especially underground workings, exists. If mine workings could have been isolated hydrologically, operators, who must pump as much as 23 tons of water per ton of coal from the anthracite mines of Pennsylvania (Ash and others, 1957), could have saved a great amount of money.

\section{ROLE OF AIR AND ORGANISMS}

The ultimate source of water in mines is some form of atmospheric precipitation. This precipitation is assumed to be saturated with atmospheric oxygen upon its arrival at the land surface. A further assumption is that no oxygen is lost or consumed by organisms or organic material before contacting pyrite $\left(\mathrm{FeS}_{2}\right)$ in or near the coal (Lorenz, 1962; Moulton, 1957). One of the postulated reactions for the oxidation of pyrite (or marcasite, another form of $\mathrm{FeS}_{2}$ ) is

$$
2 \mathrm{FeS}_{2}+7 \mathrm{O}_{2}+2 \mathrm{H}_{2} \mathrm{O}=2 \mathrm{FeSO}_{4}+2 \mathrm{H}_{2} \mathrm{SO}_{4} \text {. }
$$

The solubility of atmospheric oxygen in water is 15 parts per million (ppm) at $0^{\circ} \mathrm{C}$ (Coker, 1954, p. 24). The ferrous-iron concentration in the mine water from reaction 1 could only be $7.3 \mathrm{ppm}$. It might be argued that if the oxygen were not supplied as a gas dissolved in water but as air flowing through the mine openings, the oxygen from the air would dissolve in the mine water and react with iron disulfide to produce more than 7.3 ppm ferrous iron in solution. Such an argument is not entirely plausible, however, because aqueous solutions which contain detectable ferrous iron $(0.01$ ppm by normal analytical methods) oxidize when exposed to air and yield ferric iron either in solution or in a precipitate.

Iron oxy-hydroxide ("rust") staining is found where mine water overflows onto the land surface. Braley (1954, p. 32-33) gives empirical evidence for the complete oxidation of $\mathrm{Fe}^{+2}$ in acid mine effluent upon exposure to air. If air tends to oxidize the ferrous ion in solution, the concentrations of ferrous ion (commonly a few hundred to a few thousand parts per million) reported in mine water (Braley, 1954) probably could not be attained by the action of air. Furthermore, in the presence of a large quantity of organic material (coal), a rapid depletion of oxygen would be expected owing to the oxidation of the organic material. Because the oxygen concentration in the mine water can be expected to be low, another parameter, the redox potential, must be introduced for measuring the oxidation state of the mine water. The redox potential is here defined as the potential of a noble-metal electrode in the solution as measured against a hydrogen electrode (for which $E^{\circ}=0$ ), with positive values more oxidizing (European convention). Germanov and others (1959) point out that significant measurements of dissolved oxygen and redox potential are mutually exclusive. If dissolved 
oxygen is detectable, the redox potential is not reproducible-that is, the oxygen electrode is irreversible. If the dissolved-oxygen concentration is below the threshold of detection, the redox potential may be a quantitative measure of the oxidation state of the solution. Barnes and Back (1964) show that when organic material is in contact with ground water, reliable redox potentials can be measured and interpreted in terms of the solubility of iron species.

A number of authors (Lorenz, 1962; Hanna and others 1961; Moulton, 1957; Braley, 1954; and Leathen, 1952) stress the role of organisms in producing acid in mines. Life processes require energy, and organisms in systems closed to radiant energy must rely on chemical energy available in the system for their life processes. In utilizing the chemical energy the organisms tend to drive the chemical species toward a more stable state. Hence, in the absence of an external energy source, such as sunlight, the organisms serve as catalysts. A catalyst increases the rate of a reaction and frequently produces a particular product, but the products are always more stable than the reactants. The role of organisms in the mine-water environment is to hasten the attainment of a more stable state, but, given sufficient time, the same final (equilibrium) state would result by either organic or inorganic paths.

Attempts to apply bactericides in mines have not been successful (Lorenz, 1962, p. 21), and, in terms of prevention, applying bactericides over the enormous area of recharge of the mines probably would not be feasible.

\section{OXIDATION-REDUCTION, A MAJOR FACTOR}

Barnes and Back (1964) show that the maximum concentration of ferric ion in ground waters can be calculated from the solubility of $\mathrm{Fe}(\mathrm{OH})_{3}$ by using the data for $25^{\circ} \mathrm{C}$ cited by Hem and Cropper (1959). The reaction is dependent on the $\mathrm{pH}$ of the solution, as

$$
\mathrm{Fe}(\mathrm{OH})_{3}+3 \mathrm{H}^{+1}=\mathrm{Fe}^{+3}+3 \mathrm{H}_{2} \mathrm{O}
$$

for which the equilibrium constant is

$$
K_{1}=\alpha_{\mathrm{Fe}^{+3}}\left(\alpha_{\mathrm{H}^{+1}}\right)^{-3}
$$

where $\alpha$ is the effective or thermodynamic concentration. Defining

we find

$$
\mathrm{pH} \equiv-\log \alpha_{\mathbf{H}^{+1}},
$$

$$
K_{1}=\left(\alpha_{\mathrm{Fe}_{\mathrm{e}}}+3\right) 10^{3 \mathrm{pH}} \text {. }
$$

By using Hem's solubility constant and appropriate conversion factors, the activity of ferric ion can be computed from

$$
\alpha_{\mathrm{Fe}_{\mathrm{e}}}+3(\mathrm{ppm})=3.30 \times 10^{9-3 \mathrm{pH}} .
$$

The activity or effective concentration of an ion can be converted to the concentration as determined by chemical analysis through the definitional equation

$$
\gamma_{\text {ion }}=\frac{\alpha_{\text {ion }}}{C_{\text {ion }}}
$$

where $\gamma_{\text {ion }}$ is the activity coefficient of the ion and $C_{\text {ion }}$ is the concentration of the ion by chemical analysis. For ideal solutions, $\gamma_{\text {ion }}=1$.

Useful activity coefficients of ions can be computed for solutions as much as 0.1 molal (Klotz, 1950) in total ionic strength; beyond this concentration the Debye-Hückel limiting law does not give reliable activity coefficients. Hem (1960) has calculated the activity coefficient of the ferric ion to total salt concentrations of 0.1 molal; $\gamma_{\mathrm{Fe}+3}$ is between 1.0 and 0.2 and decreases as total salt concentration increases.

The range of concentration of ferric ion has been calculated for the limits of reliability of $\gamma_{\mathrm{Fe}+3}$ as $\mathbf{a}$ function of $\mathrm{pH}$ (table 1 ).

From the solubility of $\mathrm{Fe}(\mathrm{OH})_{3}$ a maximum redox potential (Eh) for mine water can be computed as a function of ferrous-iron concentration and $\mathrm{pH}$. The pertinent reaction is

$$
\mathrm{Fe}^{+2}=\mathrm{Fe}^{+3}+\epsilon^{-1},
$$

where

$$
\epsilon^{-1} \text { represents an electron. }
$$

The redox potential is computed from the classical Nerst equation

$$
\mathrm{Eh}=E^{\circ}+\frac{R T}{n F} \ln \frac{\alpha_{\mathrm{Fe}_{0}}+3}{\alpha_{\mathrm{Fe}^{2}}}
$$

\begin{tabular}{|c|c|c|}
\hline $\mathrm{pH}$ & $\begin{array}{l}\text { Ideal solution } \\
\quad(\mathrm{ppm})\end{array}$ & $\begin{array}{c}0.1 \text { molal solution } \\
\left(\gamma \mathrm{Fe}^{+3=0.2)}\right. \\
(\mathrm{ppm})\end{array}$ \\
\hline 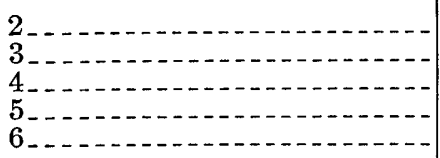 & $\begin{array}{l}\text { 3. } 3 \times 10^{3} \\
\text { 3. } 3 \\
\text { 3. } 3 \times 10^{-3} \\
\text { 3. } 3 \times 10^{-6} \\
\text { 3. } 3 \times 10^{-9}\end{array}$ & $\begin{array}{l}\text { 1. } 65 \times 10^{4} \\
\text { 1. } 65 \times 10^{-2} \\
\text { 1. } 65 \times 10^{-2} \\
\text { 1. } 65 \times 10^{-5} \\
\text { 1. } 65 \times 10^{-8}\end{array}$ \\
\hline
\end{tabular}

where

$E^{\circ}$ is the standard potential,

$R$ is the gas constant,

$T$ is the temperature in degrees Kelvin,

$n$ is the number of electrons in the reaction, and

$F$ is the Faraday constant.

TABLE 1.-Maximum range of concentration of $\mathrm{Fe}^{+3}$

At $25^{\circ} \mathrm{C}$, equation 9 reduces to

$$
\mathrm{Eh}=0.771+0.059 \log \frac{\alpha_{\mathrm{Fe}^{+3}}}{\alpha_{\mathrm{Fe}^{+2}}}
$$


The range of $\mathrm{Eh}$ for mine waters having activities of ferrous ion between $10 \mathrm{ppm}$ and $1,000 \mathrm{ppm}$ in equilibrium with $\mathrm{Fe}(\mathrm{OH})_{3}$ has been calculated and is shown in figure 1. Although $\alpha_{\mathrm{Fe}}+2=1,000 \mathrm{ppm}$, such solutions would contain ferrous ion concentrations of about several thousand parts per million. The bulk of mine water is tentatively assumed to have maximum $\mathrm{Eh}$ values in the range shown. Eh values for various oxygen partial pressures are shown in the same figure. The Eh values for the oxygen pressures are obtained from the equation used by Garrels (1960, p. 109):

$$
\mathrm{Eh}=1.23+0.01475 \log _{10} P_{\mathrm{O}_{2}}-0.059 \mathrm{pH} .
$$

The Eh for one atmosphere of pure oxygen, the normal earth's atmosphere, and the oxygen pressure representing the threshold of determination of oxygen from the modified Winkler method are given. The lower limit of oxygen from the modified Winkler method is $0.01 \mathrm{ppm} \mathrm{O}_{2}$, which would give a partial pressure of oxygen of $1.2 \times 10^{-3} \mathrm{~atm}$ at $25^{\circ} \mathrm{C}$.

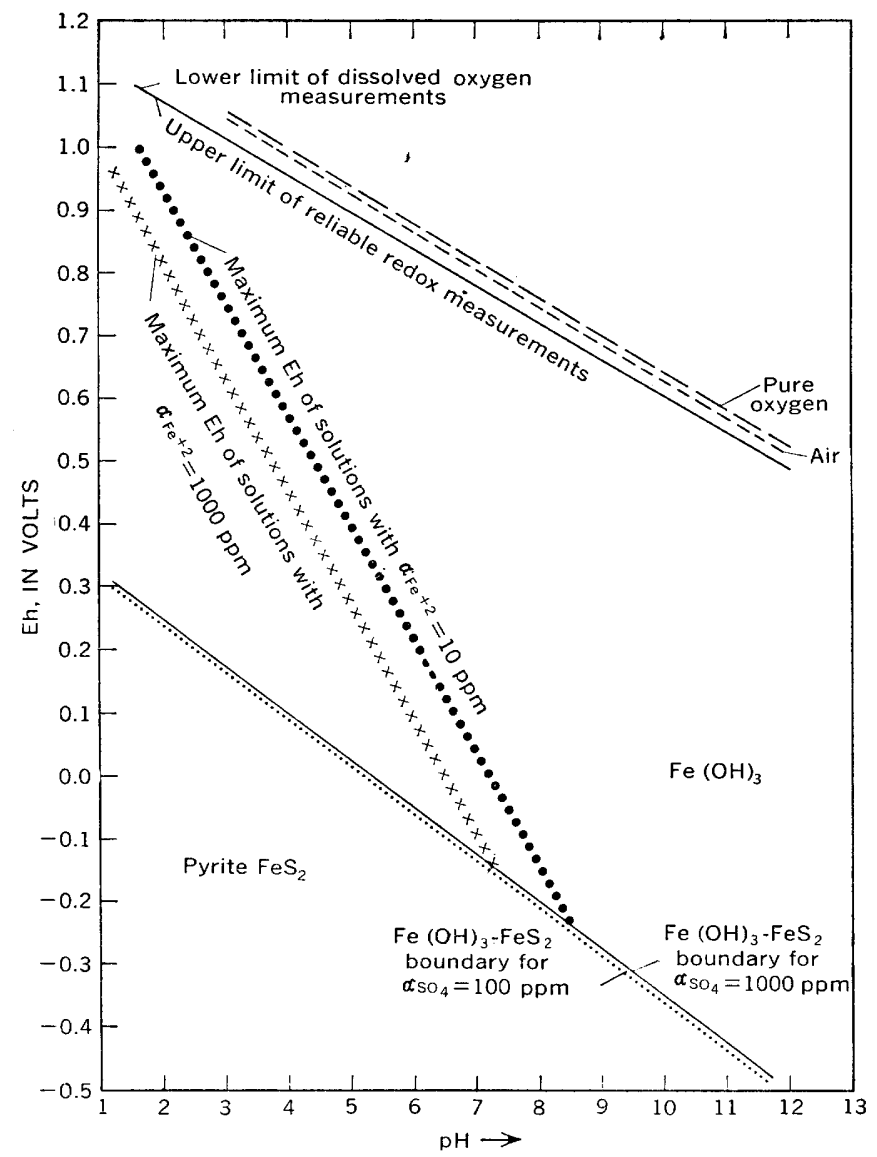

FIQURE 1.-A diagram from theoretical considerations showing postulated properties of mine water.

Also appearing in figure 1 are two boundaries representing stability between pyrite and ferric hydroxide. The higher boundary is for water having a sulfate activity of $1000 \mathrm{ppm}$, and the lower boundary is for water with a sulfate activity of $100 \mathrm{ppm}$. Mine water usually lies in this range. The reaction along the boundary is

$$
\mathrm{FeS}_{2}+11 \mathrm{H}_{2} \mathrm{O}=2 \mathrm{SO}_{4}^{-2}+\mathrm{Fe}(\mathrm{OH})_{3}+19 \mathrm{H}^{+1}+15 \epsilon^{-1} \text {, }
$$

for which, at $25^{\circ} \mathrm{C}$, by using the data of Latimer (1952, p. 12, 39, 221),

$$
\operatorname{Eh}_{\left(25^{\circ} \mathrm{C}\right)}=0.413+\frac{0.059}{15} \log \left(\alpha_{\mathrm{SO}_{4}}-2\right)^{2}\left(\alpha_{\mathrm{H}^{+1}}\right)^{19} .
$$

An order of magnitude of change in sulfate activity shifts the boundary only 0.009 volt. The boundaries are the highest possible in terms of $\mathrm{Fh}$; any less hydrous ferric phase would be more stable and would shift the boundary down in Eh. Any less stable sulfide (marcasite or "amorphous pyrite") would also move the boundary downward. The partial pressure of hydrogen along the boundary is much higher than the partial pressure of oxygen (Garrels, 1960, p. 108). Inevitably, as long as the water remains in contact with pyrite, the Eh of the water decreases, although at an unknown rate, toward the pyrite stability limit. Bacteria, if present, merely catalyze the approach to equilibrium.

\section{POSSIBLE ANAEROBIC REACTIONS}

The information above and in figure 1 indicates clearly that aqueous solutions in mines may contain less than detectable amounts of dissolved oxygen but easily detectable amounts of ferrous ion at redox potentials far lower than those of oxygen-containing solutions. As a consequence, some other reaction must be substituted for the one given (equation 1). The following equation is suggested:

$$
\mathrm{FeS}_{2}+8 \mathrm{H}_{2} \mathrm{O}=\mathrm{Fe}^{+2}+2 \mathrm{SO}_{4}^{-2}+2 \mathrm{H}^{+1}+7 \mathrm{H}_{2} \text {. }
$$

The hydrogen may be effectively consumed by reactions such as partial hydrogenation of the nonaromatic coal fraction, a suggestion by Irving Breger (oral communication, 1963). Solution of the hydrogen in the coal should be considered as a possible sink for whatever hydrogen is produced. A perhaps less attractive suggestion is the possible action of the hydrogen utilized by organisms during the production of methane. Such reactions are known in some environments (ZoBell, 1947), and possibly the same type reaction may be found during further study of mine water, although coal may be an unfavorable substrate. In any event, for pyrite to oxidize and give sulfate ions, some other substance must be reduced. Dissolved oxygen alone cannot conceivably be the oxidizing agent, nor is it plausible that the organic matter (coal) present is further reduced by the oxidation of the 
pyrite. The only obvious alternative is to reduce water as is suggested in equation 14 . The fate of the hydrogen is not known, although it may escape as methane or some other organic constituent, or react with oxidized species such as $\mathrm{Fe}_{2} \mathrm{O}_{3}$ to produce $\mathrm{Fe}^{+2}$ in solution and water.

The observation of wide $\mathrm{pH}$ ranges in mine water leads to the obvious conclusion that other reactions must occur, such as the reaction on siderite $\left(\mathrm{FeCO}_{3}\right)$ which is reportedly found in the coal measures:

$$
\mathrm{FeCO}_{3}+2 \mathrm{H}^{+1}=\mathrm{Fe}^{+2}+\mathrm{H}_{2} \mathrm{O}+\mathrm{CO}_{2} .
$$

Calcite $\left(\mathrm{CaCO}_{3}\right)$ would, of course, react in a manner analogous to the reaction of siderite. Clays and other silicates may be expected to dissolve as the hydrogenion concentration increases, and concomitant high aluminum concentrations result. As the mine water moves into an aerated environment, the ferrous ion oxidizes as follows:

$$
4 \mathrm{Fe}^{+2}=4 \mathrm{Fe}^{+3}+4 \epsilon^{-1}
$$

requiring a reduction reaction involving other species, such as for oxygen,

$$
\mathrm{O}_{2}+4 \mathrm{H}^{+1}+4 \epsilon^{-1}=2 \mathrm{H}_{2} \mathrm{O} \text {. }
$$

Combining equations 16 and $17, \mathrm{pH}$ apparently would rise, as

$$
4 \mathrm{Fe}^{+2}+\mathrm{O}_{2}+4 \mathrm{H}^{+1}=4 \mathrm{Fe}^{+3}+2 \mathrm{H}_{2} \mathrm{O} \text {; }
$$

for each ferrous ion oxidized, one hydrogen ion reacts. The difficulty is that the solubility of ferric ion is strictly limited by $\mathrm{pH}$. From equation 2,

$$
\mathrm{Fe}^{+3}+3 \mathrm{H}_{2} \mathrm{O}=\mathrm{Fe}(\mathrm{OH})_{3}+3 \mathrm{H}^{+1} \text {, }
$$

as each ferric ion precipitates, three hydrogen ions are produced.

A strict relation between total iron in solution and $\mathrm{pH}$ does not exist. The relation depends on whether or not a side reaction with a carbonate has taken place, how far the oxidation of the initially reduced mine water has progressed, and how much ferric ion has precipitated.

\section{GEOCHEMICAL IMPLICATIONS}

There are some significant implications in the view of acid mine water presented here. If the suggested reactions dissolving pyrite or its polymorphs are correct, sealing a mine to prevent ingress of air may not solve mine-acid problems satisfactorily. In some mines the exclusion of air may lead to the discharge of mine water laden with ferrous iron which oxidizes and produces the two undersirable effects shown in equation 20.

$$
4 \mathrm{Fe}^{+2}+\mathrm{O}_{2}+10 \mathrm{H}_{2} \mathrm{O}=4 \mathrm{Fe}(\mathrm{OH})_{3}+8 \mathrm{H}^{+1} .
$$

First, the precipitation of larger amounts of ferric iron would discolor the bed, smother bottom-dwelling organisms, and lower the $\mathrm{pH}$ of the water. Second, the oxidation of ferrous iron tends to decrease the amount of oxygen dissolved in the stream and, thereby, to decrease the amount of oxygen available to oxygenconsuming organisms.

Because the reaction that dissolves pyrite causes lower redox potentials and higher ferrous and sulfate ion concentrations as equilibrium is approached, delaying the passage of water through the mine by partial sealing might conceivably aggravate the problem of treating the effluent by allowing the solutions to become more concentrated.

As mentioned previously, no practical method of hydrologically isolating mines has been found. Exploiting the resource increases the permeability of the entire geologic section in underground mining. An inevitable consequence of underground mining is gradual failure of the overlying rock partly by plastic deformation and partly by brittle failure resulting in cracks. The failure of old mines in the northern anthracite region of Pennsylvania has resulted in several feet or more of subsidence. To seal such a hydrologically open system that has miles of subsurface workings is impossible. As a consequence, ground water can flow preferentially through the mines and be free to contact pyrite. Thus, mine sealing might lead to an eventual steady-state discharge of mine water as great as though the mine were unsealed but having longer contact time and more opportunity to approach equilibrium with respect to sulfides.

Observations of mine acid production neither prove nor disprove the theoretical geochemistry presented here. There are reports (J. E. Kinney, written communication, 1963) of mine-sealing projects during which high initial acid production rates declined with time as though impoundment inhibited the acidproduction process. On the other hand, the literature (Braley, 1954) indicates that certain sealed mines yield solutions having much higher acid and iron concentrations than are common for open mines. Such inconsistencies indicate the need for better integration of theoretical studies, laboratory experiments, and field observations.

\section{CHEMICAL EFFECTS OF NEUTRALIZATION PRACTICES}

Chemical neutralization within a mine would not significantly alter the theoretical model presented. If, for example, limestone were dumped into a mine, the reactions would be the same as if carbonate minerals were naturally present, as

$$
\mathrm{CaCO}_{3}+2 \mathrm{H}^{+1}=\mathrm{Ca}^{+2}+\mathrm{H}_{2} \mathrm{O}+\mathrm{CO}_{2} .
$$


The reaction would raise the $\mathrm{pH}$, and precipitation of ferric hydroxide would be expected. The addition of limestone in the mine would, in principle, amount to replacing the hydrogen ions and ferrous ions with an equivalent amount of calcium ions. The water would be very hard, and the hardness, being noncarbonate, would be difficult to remove; but the water might not become simply a neutral calcium sulfate solution because the neutralization may not stop the pyrite from dissolving. If it did not stop the pyrite from dissolving, the mine water would still tend toward the phase boundary of $\mathrm{Fe}(\mathrm{OH})_{3}$ and pyrite but would increase in calcium and sulfate concentrations. Direct treatment of minewater effluent through a trough containing coarse limestone has been attempted (Lorenz, 1962, p. 10), but this process failed because ferric hydroxide precipitated on the limestone and armored it against further solution.

In attempts to decrease the corrosiveness of mine water and to improve the quality of water discharged into surface-water resources, coal-mine operators have used various liming treatments-using slaked lime and powdered limestone (Ash and others, 1951, 1957)-for neutralization of acid mine waters. Such treatment is continued only as long as the mine or breaker is in operation and, of course, is useful only where a point discharge of mine water is involved.

For small scattered inflows of mine drainage into streams (seepage), the neutralization methods suitable for point sources may not apply. The recovery of acid streams to more natural conditions depends on the geology and hydrology of the particular drainage basin. It is well known that the acid streams recover in the course of travel as the iron precipitates and the acid is diluted and neutralized by contact with alkaline minerals in the streambed and with diluting waters. Unfortunately, most streams in anthracite coal fields and in some bituminous coal fields are in contact only with sandstone, shale, and coal. Although streams may have high $\mathrm{pH}$ values, the buffering capacity of the streams are low, as bicarbonate concentrations are about $10-50$ ppm. By contrast, bicarbonate concentrations in streams in areas underlain by limestone are from 50 to $200 \mathrm{ppm}$, and the buffer or neutralization capacity is proportionately higher. As a consequence, the recovery mechanism of streams in the coal fields is often mostly dilution, and neutralization does not occur until tributaries from areas underlain by calcareous rocks enter the acid stream.

An example of natural neutralization occurred where Maiden Creek discharges into the Schuylkill River above Reading, Pa. (Ash and others, 1951, p. 40). While having a discharge that was three times its normal flow, the Schuylkill received enough bicarbonate from Maiden Creek to raise the $\mathrm{pH}$ of the river from 4.4 to
5.9 ; the amount of influent bicarbonate was equivalent to a maximum of 70 tons of limestone a day, and it played a major role in neutralizing the acid accumulated from 880 square miles of watershed (U.S. Geol. Survey, 1960) and 45 miles of mainstem channel when the flow of the river was three times normal. Thus, it may be feasible to use quarry-run limestone for raising the buffer capacity of parts of the coal-field drainage and beneficiating reaches of streams which are now lost for recreational or sewage consumption purposes because of an acid condition. In attempting such neutralization, placing the limestone upstream from the coal-mine effluent or in upstream iron-free tributaries should be more effective. If limestone is placed in surface water rich in ferrous ions, the precipitation of the ferric hydroxide would tend to insulate the limestone and block the desired reaction.

Neutralization admittedly is not an ideal solution to the mine-waste problem. However, less orthodox treatment3, such as removal of sulfate ion by an electrolytic process using lead electrodes, probably cannot be justified in the present situation.

\section{SUMMARY}

Geochemical considerations of the mine-drainage problem indicate that air is not the only major source of mine acid; so, mine sealing may not provide a completely satisfactory solution to the problem. Indirect neutralization by use of limestone appears to have much merit as an interim corrective treatment. Theoretical geochemistry should be considered carefully in future research on mine sealing or other inhibitive or corrective processes because the theoretical model provides a basic insight into the causes and effects of acid mine drainage.

\section{REFERENCES}

Ash, S. H., Dierks, H. A., and Miller, P. S., 1957, Mine flood prevention and control: U.S. Bur. Mines Bull. 562, 100 p.

Ash, S. H., Felegy, E. W., Kennedy, D. O., and Miller, P. S., 1951, Acid-mine-drainage problems, anthracite region of Pennsylvania: U.S. Bur. Mines Bull. 508, 72 p.

Barnes, Ivan, and Back, William, 1964, Geochemistry of ironrich ground waters of southern Maryland: Jour. Geol. (in press).

Braley, S. A., 1954, Summary report: Mellon Inst. Indus. Research, Pennsylvania Dept. Health, Indus. Fellowships 1-7, $279 \mathrm{p}$.

Coker, Robert E., 1954, Streams, lakes, ponds: Chapel Hill, N.C., North Carolina Univ. Press, 327 p.

Garrels, Robert M., 1960, Mineral equilibria at low temperature and pressure: New York, Harper \& Bros., 254 p.

Germanov, A. L., Volkov, G. A., Lisitsin, A. K., and Serebrennikov, V. S., 1959, Investigation of the oxidation-reduction potential of ground waters: Geochemistry, no. 3, p. 322-329.

Hanna, G. P., Jr., and others, 1961, Analysis of fundamentals of acid mine drainage: Ohio State Univ. Eng. Expt. Sta. Water Resources Center Rept. 175, 76 p. 
Hem, J. D., 1960, Restraints on dissolved ferrous iron imposed by bicarbonate, redox potential, and pH: U.S. Geol. Survey Water-Supply Paper 1459-B, 55 p.

Hem, J. D., and Cropper, W. H., 1959, Survey of ferrous-ferric chemical equilibria and redox potentials: U.S. Geol. Survey Water-Supply Paper 1459-A, 31 p.

Klotz, Irving M., 1950, Chemical thermodynamics: Englewood Cliffs, N.J., Prentice-Hall, 369 p.

Latimer, W. M., 1952, Oxidation potentials: Englewood Cliffs, N.J., Prentice-Hall, 392 p.

Leathen, William W., 1952, Special summary report on microbiological studies of bituminous coal mine drainage: Mellon Inst. Indus. Research, Pennsylvania Dept. Health, Indus. Fellowship 326B-6, 54 p., and supplement, 9 p.
Lorenz, Walter C., 1962, Progress in controlling acid mine water-a literature review: U.S. Bur. Mines Inf. Circ. 8080, $40 \mathrm{p}$.

Moulton, E. Q., ed., 1957, The acid mine-drainage problem in Ohio: Ohio State Univ. Eng. Expt. Sta. Bull. 166, 158 p.

ZoBell, Claude E., 1947, Microbial transformation of molecular hydrogen in marine sediments with particular reference to petroleum: Am. Assoc. Petroleum Geologists Bull., v. 31, no. 10, p. 1709-1751.

U.S. Geological Survey, 1960, Compilation of records of surface waters of the United States through September 1950, Part 1-B, North Atlantic slope basins, New York to York River: U.S. Geological Survey Water-Supply Paper 1302, 679 p. 
